\title{
ロボットハンドによるパワーグラスプの最適化
}

\author{
余永*1 竹 内 賢 $一 * 2$ 吉 川 恒 夫*2

\section{Optimization of Robot Hand Power Grasps}

\author{
Yong $\mathrm{Yu}^{* 1}$, Kenichi Takeuchi ${ }^{* 2}$ and Tsuneo Yoshikawa*2
}

\begin{abstract}
When an object is grasped by a multifingered hand with power grasp, there are an infinite number of possible power grasp forms, provided by combinations of the hand shape, the contact positions between fingers and the object, and the joint torques of the hand. To plan a power grasp, it is necessary to know, by some prior evaluation, which form is most suitable among these forms. This paper proposes a technique for automatically obtaining optimal power grasp. By analyzing the degree of freedom of the force space caused by frictional contacts between fingers and object, the conditions and mechanical properties of power grasp are described. Also, the region of feasible joint torques for power grasp is derived. Then, an optimal power grasp form is defined and its determination procedure is established. Lastly, numerical examples are performed to verify the effectiveness of the proposed approach.
\end{abstract}

Key Words: Robot Hand, Power Grasp, Degree of Freedom of Force Space, Optimization, Object Manipulation

1. 緒言

人間は手を用いて物をつかんだり，つかんだ物の位置や姿勢 を変えることができる。このような作業をロボットに行わせる ときの手先機構として, シンプルな物としてはグリッパがあり, さらに多様な対象物を自在に扱うためには人間の手を模した多 関節多指型のロボットハンドが有効であると考えられる。これ らに関しては, ロボットハンドによる把持と操りの問題として, ロボットハンドの汎用性を高め, より高度な作業を実現するた めに様々な研究がなされている $[10]$.

従来の研究では, 指先接触による物体の把持や操りに関する ものが多かった．指先接触ではそれぞれの接触点の位置どりの 制限が小さく，滑りやころがりによって接触点の移動がしやす いということから, 操りには適した把持であると考えられる. しかし人間が手で物体を「つかむ」場合, 特にその物体の動き を完全に拘束したいときには，普通，指先のみではなく指の腹 や掌も物体に接触させて包み込むようにつかむ. ロボットハン ドにおいても同様に多関節指の中間のリンクにも物体を接触さ せることで，物体をより安定に把持することができると考えら れる。このような把持は, Whole-limb Manipulation [1]ある いは Enveloping Graspなどと呼ばれている.

\footnotetext{
原稿受付 1998 年 5 月 11 日

*1 鹿児島大学工学部

*2 京都大学大学院工学研究科

${ }^{* 1}$ Fuculty of Engineering, Kagoshima University

${ }^{* 2}$ Graduated School of Engineering, Kyoto University
}

中でも，各関節にあらかじめ適当な関節トルクを与えておけ ば，把持している物体に有限の大きさの任意の方向の並進およ び回転の外力が働いたときに初期の関節トルクを変化させるこ となく接触力の自動的な变化によってその外力に対抗する力を 生成してもとの把持状態を維持できるものが存在する。 そのよ うな把持はパワーグラスプと呼ばれている [4]〜 [8].

指先での把持では一般に対象物に働く外乱がどんなに小さい ものであっても，各関節のトルクを制御しなければ把持の平衡 を保つことはできないのに対して，パワーグラスプではあらか じめ与えたトルクを制御することなく外乱に対して把持の平衡 を保つことができる点が， ロバストな把持として有効であると 考えられる。

小俣ら [5] はパワーグラスプであるための条件を対象物と指 リンクの間の運動学的な拘束条件によって表し，さらに滑りの 方向の拘束から発生可能な接触力の範囲を示している. 張ら [6] は対象物が動き出す直前の接触力を計算することにより, 対象 物が動き始める臨界外力を求め, それをパワーグラスプのロバ スト性の評価に用いることを提案している。

ところで，ある物体がパワーグラスプによって把持されてい るとき, そのパワーグラスプの形態は，把持に用いるロボット ハンドの形，ロボットハンドの指リンクと物体との接触位置, ロボットハンドの関節トルクの值の組み合わせにより無数に存 在する。実際に把持をするためにはこれら無数に存在するパ ワーグラスプの形態の中から何らかの評価基準をもって適当な ものを選び出す必要がある，そこで本論文では，まず指リンク と物体との接触による力空間の自由度の解析に基づきパワーグ 
ラスプの条件と力学特性を考察し, ついで安定把持するための 関節トルクの範囲を与える。そして把持する対象物体が与えら れたときの最適なパワーグラスプを定義し, その決定法を示す. さらに数值例で検証する.

\section{2. パワーグラスプの条件とカ学特性}

本章では, どのような把持がパワーグラスプとなるのかを述 ベる．まず指リンクと物体との接触による力空間の自由度につ いて解析しパワーグラスプの条件を示し, 次にパワーグラスプ によって抗することのできる外力の空間の相似性, さらに安定 把持するための可能な関節トルクを考察する.

Fig. 1 のような系において次の仮定が成立するものとする.

・対象物は凸な多面体であるとする。

・指の中間リンク（または指先）は対象物のエッジ（または 平面）と摩擦あり点接触しているものとする.

-ベースは対象物の頂点と摩擦あり点接触しているものとす る．ただしベースには接触点を持たない場合もある．

・各指リンクおよびベースにはたかだか一つの接触点がある ものとする。

また，ベースに固定された座標系を基準座標系 $\Sigma_{R}$, 対象物 に固定された座標系を対象物座標系 $\Sigma_{O}$ とする。

さらに次のような記号を定義する。ただし指の本数は $K$ で あるとし, 添字 $i(=1,2, \cdots, K)$ は $i$ 番目の指を添字 0 はべー スをそれぞれ表す。

$M_{i}: i$ 番目の指の接触点数

$M:$ 全接触点数 $\left(=\Sigma_{i=0}^{K} M_{i}\right)$

$L_{i}: i$ 番目の指の関節数

$L$ : 全関節数 $\left(=\Sigma_{i=0}^{K} L_{i}\right)$

$C_{i j}: i$ 番目の指の $j$ 番目の接触点

$r_{i j}$ : 対象物座標系原点から接触点 $C_{i j}$ までのベクトル

$n_{i j}$ : 接触点 $C_{i j}$ における対象物に内向き単位法線べクト ル（指の中間リンクと対象物のエッジの双方に，また は指先と接触した対象物の平面に垂直な方向）

ただし $L_{i}$ については，ある関節から先のリンクに接触点をも たない場合その関節は数には含めない。また本論文において， ベースとの接触点が存在するとき，その接触点における* $*_{i j} に$ 対応するものは*。とする.

本論文では，三次元空間内の運動を考える場合において議論 を行う。ただし得られた結果は二次元平面内の連動を考える場 合にも適用できる。三次元空間内の運動において, 三次元並進

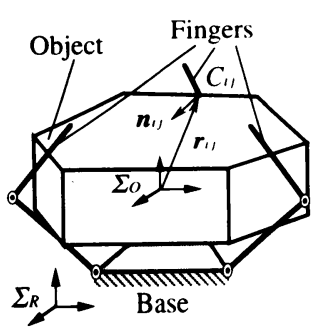

(a) Case for 3D

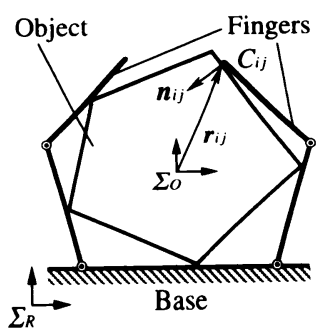

(b) Case for 2D
Fig. 1 Object and robot hand
力成分と三次元回転力成分を合わせたものを六次元力とし，す べての発生可能な六次元力からなる凸空間を力空間と定義す る.これに対応して平面内の運動における力空間は, 二次元並 進力成分と一次元回転力成分がある三次元力からなる凸空間と する. 力空間において正負いずれの側へも力が発生できる互い に独立な方向の数を，力空間の自由度と定義する．一般に，場 合によって力空間には力の方向の制限が存在する. 方向に制限 を有する力空間の自由度はその空間に含まれる線形空間の次元 の数と一致している．指リンクと対象物との接触による力空間 の自由度を考えると，把持がパワーグラスプであるための条件 は以下の定式化により導かれる。

2.1 パワーグラスプの把持形態条件

まず，指リンク $i$ と対象物とが点 $C_{i j}$ で一点接触している場 合を考える. 接触点 $C_{i j}$ から対象物に働く力を $\boldsymbol{f}_{i j} \in \boldsymbol{R}^{3}, \boldsymbol{f}_{i j}$ により抵抗可能な，対象物座標系原点に働く並進および回転の 外力を $\boldsymbol{t}_{\boldsymbol{e}} \in \boldsymbol{R}^{6}$ とすると, 接触力 $\boldsymbol{f}_{i j}$ と外力 $\boldsymbol{t}_{\boldsymbol{e}}$ との関係は静 的な釣り合いがあるとき，次のようになる。

$$
\boldsymbol{W}_{i j}^{T} \boldsymbol{f}_{i j}+\boldsymbol{t}_{e}=\mathbf{o}
$$

ここで, $\boldsymbol{W}_{i j} \triangleq\left[\begin{array}{ll}\boldsymbol{I}_{3} & \boldsymbol{R}^{T}\left(\boldsymbol{r}_{i j}\right)\end{array}\right] \in \boldsymbol{R}^{3 \times 6}$ である.ただし $\boldsymbol{R}\left(\boldsymbol{r}_{i j}\right)$ は $\boldsymbol{R}\left(\boldsymbol{r}_{i j}\right) \boldsymbol{f}_{i j} \triangleq \boldsymbol{r}_{i j} \times \boldsymbol{f}_{i j}$ で定義される歪対称行列で あり， $\boldsymbol{I}_{*}$ は* 次元単位行列である.

一方，指リンク側の関節卜ルクベクトルを $\boldsymbol{\tau}_{i} \in \boldsymbol{R}^{L_{i}}$ とする と, $\boldsymbol{\tau}_{i}$ と各関節トルクにより発生する接触力 $\boldsymbol{f}_{i j}$ との関係は 次のようになる.

$$
\boldsymbol{J}_{i j}^{T} \boldsymbol{f}_{i j}=\boldsymbol{\tau}_{i}
$$

ここで, $\boldsymbol{J}_{i j} \in \boldsymbol{R}^{3 \times L_{i}}$ は接触点 $C_{i j}$ と各関節角度とのヤコビ 行列である.

$K$ 本の指と対象物とが指リンクや指先で $M$ 点接触している 場合を考えると, 関節卜ルクベクトル $\boldsymbol{\tau}$, 接触力ベクトル $\boldsymbol{f}$, 外力 $\boldsymbol{t}_{e}$ の三者間の関係が, 関係式 (1) と（2）により, 次の ようにまとめられる。

$$
\begin{aligned}
\boldsymbol{W}^{T} \boldsymbol{f} & =-\boldsymbol{t}_{\boldsymbol{e}} \\
\boldsymbol{J}^{T} \boldsymbol{f} & =\boldsymbol{\tau}
\end{aligned}
$$

ここで,

$$
\begin{aligned}
& \boldsymbol{f} \triangleq\left[\left(\boldsymbol{f}_{0}^{T}\right) \boldsymbol{f}_{11}^{T} \cdots \boldsymbol{f}_{1 M_{1}}^{T} \cdots \boldsymbol{f}_{K 1}^{T} \cdots \boldsymbol{f}_{K M_{K}}^{T}\right]^{T} \in \boldsymbol{R}^{3 M} \\
& \boldsymbol{\tau} \triangleq\left[\boldsymbol{\tau}_{1}^{T} \cdots \boldsymbol{\tau}_{K}^{T}\right]^{T} \in \boldsymbol{R}^{L}
\end{aligned}
$$

である。また,

$$
\begin{aligned}
& \boldsymbol{W} \triangleq\left[\left(\boldsymbol{W}_{0}^{T}\right) \boldsymbol{W}_{11}^{T} \cdots \boldsymbol{W}_{1 M_{1}}^{T} \cdots \boldsymbol{W}_{K 1}^{T} \cdots \boldsymbol{W}_{K M_{K}}^{T}\right]^{T} \in \boldsymbol{R}^{3 M \times 6} \\
& \boldsymbol{J} \triangleq\left[\begin{array}{ccccccccc}
(\mathbf{o}) & \boldsymbol{J}_{11}^{T} & \cdots & \boldsymbol{J}_{1 M_{1}}^{T} & \cdots & \cdots & \mathbf{o} & \cdots & \mathbf{0} \\
\vdots & \mathbf{o} & \cdots & \mathbf{o} & \ddots & & \vdots & \ddots & \vdots \\
\vdots & \vdots & \ddots & \vdots & & \ddots & \mathbf{0} & \cdots & \mathbf{0} \\
(\mathbf{o}) & \mathbf{o} & \cdots & \mathbf{o} & \cdots & \cdots & \boldsymbol{J}_{K 1}^{T} & \cdots & \boldsymbol{J}_{K M_{K}}^{T}
\end{array}\right]^{T}
\end{aligned}
$$


である．ただし本論文では，ベースとの接触点が存在しないと きにはブロック行列中の（）でくくった成分は除く.

式 (4) を $f$ について解くと

$$
\boldsymbol{f}=\left(\boldsymbol{J}^{+}\right)^{T} \boldsymbol{\tau}+\left(\boldsymbol{I}_{3 M}-\boldsymbol{J} \boldsymbol{J}^{+}\right) \boldsymbol{k}_{1}
$$

となる.ここで, $\boldsymbol{J}^{+} \in \boldsymbol{R}^{L \times 3 M}$ は $\boldsymbol{J}$ の疑似逆行列を表し, $\boldsymbol{k}_{1}$ は $3 M$ 次元任意ベクトルである. 適当な関節トルク $\tau_{c}$ (その存在範 囲は 2.4 節で述べる) を取ると, 関節トルク $\boldsymbol{\tau}=\boldsymbol{\tau}_{c}=\mathrm{constant}$ のとき式（9）は次式のようになる.

$$
\boldsymbol{f}=\left(\boldsymbol{J}^{+}\right)^{T} \boldsymbol{\tau}_{c}+\left(\boldsymbol{I}_{3 M}-\boldsymbol{J} \boldsymbol{J}^{+}\right) \boldsymbol{k}_{1}
$$

上式で与えられる $\boldsymbol{f}$ は各関節にあらかじめ一定のトルクを与 えたときの接触力の候補となり得るもの（候補接触力）である. この式右辺の第二項目は，接触力空間において関節卜ルクに影 響を及ぼさない各指リンク間の内力の空間を表わすものである. 候補接触力は，この内力の空間において存在または変化すると きに関節トルクに影響を与えないと考えられる。

同様に，候補接触力空間と式 $(3)$ によって，

$$
\boldsymbol{t}_{e}=-\left[\boldsymbol{W}^{T}\left(\boldsymbol{J}^{+}\right)^{T} \boldsymbol{\tau}_{c}+\boldsymbol{W}^{T}\left(\boldsymbol{I}_{3 M}-\boldsymbol{J} \boldsymbol{J}^{+}\right) \boldsymbol{k}_{1}\right]
$$

が得られ，これは各関節にあらかじめ一定のトルクを与えたと きに候補接触力により抵抗可能な外力となり得るもの（候補外 力）である. 上式右辺の第一項目は対象物に作用する関節卜ルク $\boldsymbol{\tau}_{c}$ からの合力である. 後の 2.4 節に述べるように安定把持を維 持するために，この合力は第二項目で表される力空間内に存在 すべきである．よって，すべての候補外力からなる力空間の自由 度は，線形空間である第二項目により $\operatorname{rank} \boldsymbol{W}^{T}\left(\boldsymbol{I}_{3 M}-\boldsymbol{J} \boldsymbol{J}^{+}\right)$ となっている。

1 章で述べたように, パワーグラスプとは, 各関節にあらか じめ適当なトルクを与えておけば，把持している物体に大きさ の有限な任意方向の外力が働いたときに関節卜ルクを変化させ ず接触力の自動変化によって対抗力を生成して現把持状態を維 持できる把持である。これにより，候補外力空間が六次元の自 由度，すなわち

$$
\operatorname{rank} \boldsymbol{W}^{T}\left(\boldsymbol{I}_{3 M}-\boldsymbol{J} \boldsymbol{J}^{+}\right)=6
$$

を有すれば，パワーグラスプが実現可能である。この空間の任 意方向の力が実際に存在し抵抗可能な外力となる保証がないた め, 上式はパワーグラスプの必要条件となり, ここではパワー グラスプの把持形態条件と呼ぶことにする，仮想的にロボット ハンド，対象物の運動を二次元平面内のみとした把持の場合， 式（12）は

$$
\operatorname{rank} \boldsymbol{W}^{T}\left(\boldsymbol{I}_{2 M}-\boldsymbol{J} \boldsymbol{J}^{+}\right)=3
$$

となる．ただしこの場合 $W \in R^{2 M \times 3}, J \in R^{2 M \times 3}$ となる.

$\boldsymbol{W} \in \boldsymbol{R}^{3 M \times 6}$ と $\operatorname{rank}\left(\boldsymbol{I}_{3 M}-\boldsymbol{J} \boldsymbol{J}^{+}\right)=3 M-R_{L}$ のことか ら,パワーグラスプの把持形態条件を満たすためには

$$
\begin{array}{r}
\operatorname{rank} \boldsymbol{W}=6 \\
3 M-R_{L} \geq 6
\end{array}
$$

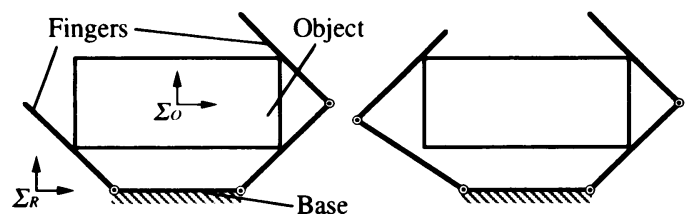

(a) $\operatorname{rank} W=3,2 M-R L=3$ $R L=3=L, M=3=L$

(b) rank $W=3,2 M-R L<3$

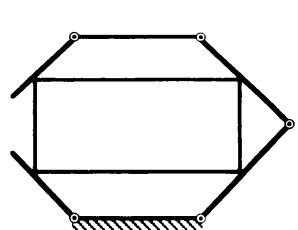

(c) rank $W=3,2 M-R L=3$ $R L=5=L, M=4<L$

Fig. 2 Examples for grasp form condition of power grasp

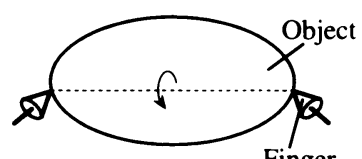

(a) $\operatorname{rank} \boldsymbol{W}=5$

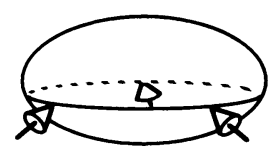

(b) $\operatorname{rank} \boldsymbol{W}=6$

Fig. 3 Examples about $\operatorname{rank} \boldsymbol{W}$

(二次元平面内の運動では $\operatorname{rank} \boldsymbol{W}=3,2 M-R_{L} \geq 3$ ) でなく てはならない.ただし $R_{L}=\operatorname{rankJ}$ である。一般に，ある指の ある接触点に対して圥長な関節がないことがすべての指に成立 する場合， $R_{L}=L$ となる (Fig. 2 参照)。また, $\operatorname{rank} \boldsymbol{W}=6$ は 3 点以上の接触点が同一直線上にない（二次元平面内の運動 では $\operatorname{rank} \boldsymbol{W}=3$ は 2 点以上の接触点がある）ときに成立する ことを意味している (Fig. 3 参照).

このように式（12）と（13）は必要十分条件ではないが，そ の把持がパワーグラスプになり得るかどうかの判別が容易にで きるため，実際にパワーグラスプでの把持を計画するときには 有効な条件であるといえる．Fig. 2 がこのためのいくつかの二 次元平面内の運動の例を示している. その中で, Fig. 2(b) を 除いて Fig. 2(a)，(c)，(d)に示された把持はパワーグラスプの 必要条件を満たして, パワーグラスプが実現可能となっている. また, Fig.2(d)のような把持は，6リンクをもつ指の根元から の 2 本のリンクと 1 リンクをもつ指との把持によりパワーグラ スプが実現可能となるので, 本質的には Fig. 2 (a) の把持と変 わらない。

\section{2 パワーグラスプの必要十分条件}

指リンクと対象物との接触力の方向は接触点での静止摩擦条 件である次式を満足しなければならない.

$$
\boldsymbol{n}_{i j}^{T} \boldsymbol{f}_{i j} \geq \frac{1}{\sqrt{1+\mu_{i j}^{2}}}\left\|\boldsymbol{f}_{i j}\right\|
$$

すなわち, 候補の接触力はこの式を満たさなければ許容な接触 力にはならない. 同様に, 候補の外力も許容接触力により抵抗 可能な外力にはならない.ここで $\mu_{i j}$ は接触点 $C_{i j}$ における最 大静止摩擦係数である。 
$M$ 個の接触点に対し式 $(16)$ を満たす $\boldsymbol{f}_{i j}$ からなる空間は

$$
\begin{gathered}
\boldsymbol{F}_{f}=\left\{\boldsymbol{f} \mid \boldsymbol{N}^{T} \boldsymbol{f} \geq \tilde{\boldsymbol{\mu}} \overline{\boldsymbol{f}}\right\} \\
\boldsymbol{N} \triangleq \\
\operatorname{diag}\left[\left(\boldsymbol{n}_{0}\right), \boldsymbol{n}_{11}, \cdots, \boldsymbol{n}_{1 M_{1}}, \cdots, \boldsymbol{n}_{K 1}, \cdots, \boldsymbol{n}_{K M_{K}}\right] \\
\quad \in \boldsymbol{R}^{3 M \times M} \\
\tilde{\boldsymbol{\mu} \triangleq} \operatorname{diag}\left[\left(\left(1+\mu_{0}^{2}\right)^{-\frac{1}{2}}\right),\left(1+\mu_{11}^{2}\right)^{-\frac{1}{2}}, \cdots,\left(1+\mu_{1 M_{1}}^{2}\right)^{-\frac{1}{2}}\right. \\
\left.\quad \cdots,\left(1+\mu_{K 1}^{2}\right)^{-\frac{1}{2}}, \cdots,\left(1+\mu_{K M_{K}}^{2}\right)^{-\frac{1}{2}}\right] \in \boldsymbol{R}^{M \times M}
\end{gathered}
$$

$$
\begin{array}{r}
\overline{\boldsymbol{f}} \triangleq\left[\left(\left\|\boldsymbol{f}_{0}\right\|\right)\left\|\boldsymbol{f}_{11}\right\| \cdots\left\|\boldsymbol{f}_{1 M_{1}}\right\| \cdots\left\|\boldsymbol{f}_{K 1}\right\| \cdots\left\|\boldsymbol{f}_{K M_{K}}\right\|\right]^{T} \\
\in \boldsymbol{R}^{M} \quad(20)
\end{array}
$$

のように表され, 凸錐となっている $[7]$. 一方, 式 (10)を満た す候補接触力の集合は

$$
\boldsymbol{F}_{J}=\left\{\boldsymbol{f} \mid \boldsymbol{f}=\left(\boldsymbol{J}^{+}\right)^{T} \widehat{\boldsymbol{\tau}}_{c} k_{c}+\left(\boldsymbol{I}_{3 M}-\boldsymbol{J} \boldsymbol{J}^{+}\right) \boldsymbol{k}_{1}, k_{c}>0\right\}
$$

となり, ここで $\widehat{\boldsymbol{\tau}}_{c}\left(=\boldsymbol{\tau}_{c} /\left\|\boldsymbol{\tau}_{c}\right\|\right)$ と $k_{c}\left(=\left\|\boldsymbol{\tau}_{c}\right\|>0\right)$ は $\boldsymbol{\tau}_{c}$ の 方向と大きさを表す。したがって, 許容接触力の集合 $\boldsymbol{F}_{J f}$ は

$$
\boldsymbol{F}_{J f}=\boldsymbol{F}_{J} \cap \boldsymbol{F}_{f}
$$

で与えられる. 式 (21) より $\widehat{\boldsymbol{\tau}}_{c}$ が一定のとき $\boldsymbol{F}_{J}$ は凸多面錐 となるので，共通集合 $\boldsymbol{F}_{J f}$ は凸錐となる．さらに，式 (22) を満たす $\boldsymbol{f}$ を式 $(3)$ に代入することで得られる $\boldsymbol{t}_{\boldsymbol{e}}$ は $\widehat{\boldsymbol{\tau}}_{c}$ を 変化させることなく抗することのできる外力である．この抵抗 可能な外力 $\boldsymbol{t}_{\boldsymbol{e}}$ のすべてからなる力空間

$$
\boldsymbol{T}_{J f}=\left\{\boldsymbol{t}_{e} \mid \boldsymbol{t}_{e}=-\boldsymbol{W}^{T} \boldsymbol{f}, \quad \boldsymbol{f} \in \boldsymbol{F}_{J f}\right\}
$$

も凸錐となる。この凸錐 $\boldsymbol{T}_{J f}$ に含まれる線形空間が

$$
\boldsymbol{T}_{J f} \cap\left(-\boldsymbol{T}_{J f}\right)
$$

となるので, 力空間 $\boldsymbol{T}_{J f}$ の自由度がこの線形空間の次元の数 となっている. パワーグラスプの定義により，抵抗可能な外力 空間 $\boldsymbol{T}_{J f}$ が六次元の自由度を有すれば，パワーグラスプの任 意方向への抵抗力が生成できる。これはパワーグラスプの必要 十分条件である。

ここでは, 力空間 $\boldsymbol{T}_{f}$ の自由度を具体的に求める方法を述 ベる。この方法は，二次元平面内運動の場合に対しては厳密性 を有するが三次元空間内運動の場合に対しては近似性をもって いる。一つの静止摩擦円錐が，平面内運動の場合には厳密的に $(h=2)$, 三次元空間内運動の場合には近似的に $(h>2)$ 円錐 と内接した $h$ 稜線の正凸多面錐で表現できる [14]. これにより 接触点 $C_{i j}$ において, 静止摩擦条件を満たす接触力は次式のよ うに表される。

$$
\boldsymbol{f}_{i j}=\sum_{l=1}^{h} k_{i j l} \boldsymbol{v}_{i j l}, \quad k_{i j l} \geq 0, l=1,2, \cdots, h
$$

ここに, $\boldsymbol{v}_{i j l}$ は接触点における摩擦多面錐の稜線をそった対象 物内部に向く単位ベクトルであり, $k_{i j l}$ は $\boldsymbol{v}_{i j l}$ 方向の接触力

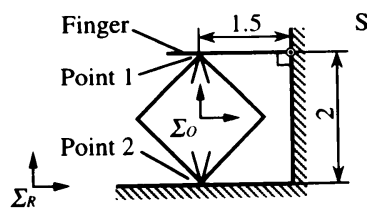

(a) $\operatorname{rank} \boldsymbol{W}^{T}\left(\boldsymbol{I}_{4}-\boldsymbol{J}_{u} \boldsymbol{J}_{a}{ }^{+}\right)=3$;

If $\mu_{1}=\mu_{2}=0.3$, rank $D_{a} 1=3$;

If $\mu_{1}=0, \mu_{2}=0.3$, rank $D_{a 2}=2$;

If $\mu 1=\mu_{2}=0$, rank $D_{a}{ }^{3}=1$.

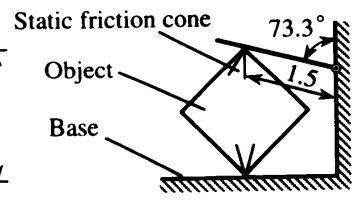

(b) $\operatorname{rank} \boldsymbol{W}^{T}\left(\mathbf{I} 4-J_{b} \boldsymbol{J}^{+}\right)=3$; If $\mu_{1}=\mu_{2}=0.3$, rank $D_{b 1}=2$; If $\mu_{1}=0, \mu_{2}=0.3$, rank $D b 2=0$; If $\mu_{1}=\mu_{2}=0$, rank $D b_{3}=0$.

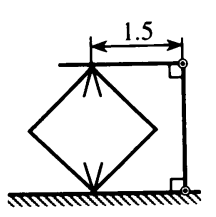

(c) rank $\boldsymbol{W}^{T}\left(\boldsymbol{I} 4-J_{c} \boldsymbol{J}^{+}\right)=2 ; \quad$ (d) $\operatorname{rank} \boldsymbol{W}^{T}\left(\boldsymbol{I}_{4}-\boldsymbol{J} d \boldsymbol{J} d^{+}\right)=2 ;$ (e) $\operatorname{rank} \boldsymbol{W}^{T}\left(\boldsymbol{I}_{2}-\boldsymbol{J} e J e^{+}\right)$ If $\mu 1=\mu 2=0.3$, rank $D_{c l}=2$; $\quad$ If $\mu 1=\mu_{2}=0.3$, $\operatorname{rankD} d \mathrm{l}=2 ; \quad=1$; If $\mu 1=0, \mu_{2}=0.3$, rank $D_{c 2}=1$; If $\mu 1=0, \mu_{2}=0.3$, rank $D_{d 2}=0 ; \quad$ rank $D_{e}=0$. If $\mu_{1}=\mu_{2}=0$, rank $D_{c} 3=1$. If $\mu_{1}=\mu_{2}=0$, rank $d_{d 3}=0$.

Fig. 4 Examples about $\operatorname{rank} D$

の成分を表し，また $h$ は摩擦多面錐稜線の数である.式 $(25)$ と（3）より，M 点接触している場合において式（25）を満た す $\boldsymbol{f}$ からなる空間 $\boldsymbol{F}_{f}$ は次のような凸多面錐で表される.

$$
\begin{aligned}
& \boldsymbol{F}_{f}=\left\{\boldsymbol{f} \mid \boldsymbol{f}=\boldsymbol{V} \boldsymbol{k}_{v}, \quad \boldsymbol{k}_{v} \geq \mathbf{o}\right\} \\
& \boldsymbol{V} \triangleq \operatorname{diag}\left[\left[\left(\boldsymbol{v}_{01} \cdots \boldsymbol{v}_{0 h}\right)\right], \cdots,\left[\boldsymbol{v}_{\left.\left.K M_{K^{1}} \cdots \boldsymbol{v}_{K M_{K} h}\right]\right]}\right.\right. \\
& \quad \in \boldsymbol{R}^{3 M \times h M} \\
& \boldsymbol{k}_{v} \triangleq\left[\left(k_{01}^{v} \cdots k_{0 h}^{v}\right) \cdots k_{K M_{K} 1}^{v} \cdots k_{K M_{K} h}^{v}\right]^{T} \in \boldsymbol{R}^{h M}
\end{aligned}
$$

凸多面錐どうしの共通集合がまた凸多面錐になるから，式 $(22)$ と式（23）より $\boldsymbol{F}_{J f}$ とその線形写像 $\boldsymbol{T}_{J f}$ は凸多面錐となる. このとき, 力空間 $\boldsymbol{T}_{J f}$ は,

$$
\boldsymbol{T}_{J f} \cap\left(-\boldsymbol{T}_{J f}\right)=\left\{\boldsymbol{D} \boldsymbol{k}_{d} \mid \boldsymbol{k}_{d} \geq \mathbf{0}\right\}
$$

のような凸多面錐で表される線形空間をもつので, $\operatorname{rank} \boldsymbol{D}$ 次 元の自由度を有する。パワーグラスプの定義により，この抵抗 可能外力空間が六次元の自由度を有すればパワーグラスプが実 現される。したがって，適当な $\boldsymbol{\tau}_{c}$ を与えた把持がパワーグラ スプであるための必要十分条件はこの抵抗可能外力空間が

$$
\operatorname{rank} \boldsymbol{D}=6
$$

次元（平面内の運動では $\operatorname{rank} \boldsymbol{D}=3$ 次元）の自由度をもつ ということである.Fig. 4 に示された例のうち, Fig.4(a)の $\mu_{1}=\mu_{2}=0.3$ の場合では, $\operatorname{rank} \boldsymbol{D}_{a 1}=3$ より抵抗可能外力 空間が三次元自由度を有するのでパワーグラスプの必要十分条 件を満たすが，その他の場合では $\operatorname{rank} \boldsymbol{D}<3$ よりパワーグラ スプの必要十分条件を満たさない.

\section{3 限界外力空間の相似性}

以上の議論では, 抵抗可能外力空間の自由度を求めるために 各空間の要素の方向のみについて考察すればよかった。しかし 
抵抗可能外力空間の相似性を検討するときには， $\boldsymbol{\tau}_{c}$ の方向で なくその大きさへの考察も必要となる.

$\tau_{c}$ の方向だけでなくその大きさも一定に与えられたとき，そ の大きさに対応して，对象物に作用する $\boldsymbol{\tau}_{c}$ からの合力の大き さは一定值となり，また，指リングと対象物間の各接触力の大 きさはそれぞれの一定值以上にはならない。これらの制約より， 一部の方向には抵抗可能な外力 $\boldsymbol{t}_{\boldsymbol{e}}$ の大きさが制限される. 正 凸多面錐で静止摩擦円錐を近似すると, このような $\boldsymbol{t}_{\boldsymbol{e}}$ のすべ てからなる抵抗可能外力空間は $\operatorname{rank} \boldsymbol{D}$ 次元自由度をもつ多面 凸集合となる。このような集合を張らは限界外力空間と呼んで いる [7]. 本節ではこの限界外力空間の相似性について述べる.

与えられた同方向であるが大きさの異なる二つの $\boldsymbol{\tau}_{c}$ に対 する抵抗可能外力空間は相似となる.式 (3) と式 (4) をまと めて,

$$
\left[\begin{array}{c}
\boldsymbol{W}^{T} \\
\boldsymbol{J}^{T}
\end{array}\right] \boldsymbol{f}=\left[\begin{array}{c}
-\boldsymbol{t}_{e} \\
\boldsymbol{\tau}
\end{array}\right]
$$

が得られる.そして, 式 (31) の両辺を $q$ 倍すると

$$
\left[\begin{array}{c}
\boldsymbol{W}^{T} \\
\boldsymbol{J}^{T}
\end{array}\right] q \boldsymbol{f}=\left[\begin{array}{c}
-q \boldsymbol{t}_{e} \\
q \boldsymbol{\tau}
\end{array}\right]
$$

が得られる. $\boldsymbol{\tau}=\boldsymbol{\tau}_{c}=$ constant としたときに, 式 (31) と式 （25）を満足する $\boldsymbol{f}$ が存在するようなすべての $\boldsymbol{t}_{\boldsymbol{e}}$ からなる限 界外力空間が存在し，この凸空間のすべての頂点（ $g$ 個）の集 合は $\boldsymbol{T}_{A}=\left\{\boldsymbol{t}_{e 1}, \boldsymbol{t}_{e 2}, \cdots, \boldsymbol{t}_{e g}\right\}$ のように記述できる。これに対 して, 式 (25) で与えられる摩擦条件は $\boldsymbol{f}$ の方向のみに依存 し大きさに依存しないから，式（25）と式（32）を共に満足す る $\boldsymbol{f}$ が存在するようなすべての $\boldsymbol{t}_{\boldsymbol{e}}$ からなる限界外力空間のす べての頂点の集合は $\boldsymbol{T}_{A}^{\prime}=\left\{q \boldsymbol{t}_{e 1}, q \boldsymbol{t}_{e 2}, \cdots, q \boldsymbol{t}_{e g}\right\}$ となる.

すなわち $\left[\begin{array}{ll}\boldsymbol{W} & \boldsymbol{J}\end{array}\right]$ が等しいパワーグラスプでは相似比 $q$ で 相似な 2 種類の関節トルクベクトルによって与えられる限界外 力空間は相似であり，その相似比は $q$ であることが分かる.

さらに，元の関節トルクベクトルによって与えられる $n$ 次元 の限界外力空間 $\boldsymbol{T}_{e}$ が原点を含む (つまり $n$ 次元の自由度を有 する）場合は $q(>1)$ 倍の関節トルクベクトルによって与えら

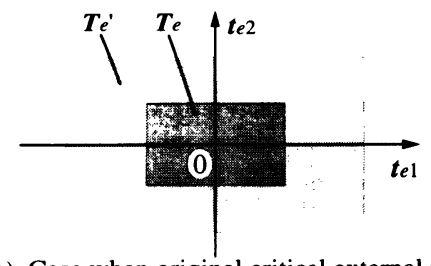

(a) Case when original critical external force space $\boldsymbol{T}_{e}$ contains the origin

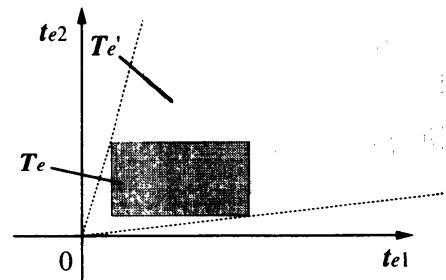

(b) Case when original critical external force space $\boldsymbol{T}_{e}$ does not contain the origin
れる限界外力空間 $\boldsymbol{T}_{e}^{\prime}$ と $\boldsymbol{T}_{e}$ の間の関係は $\boldsymbol{T}_{e} \subset \boldsymbol{T}_{e}^{\prime}$ であるが (概念図 Fig. 5 (a) 参照)，T $\boldsymbol{T}_{e}$ が原点を含まない（つまり $n$ 次 元の自由度を有しない) 場合は $\boldsymbol{T}_{e}^{\prime}$ は $\boldsymbol{T}_{e}$ すべてを含むことは ない (概念図 Fig. 5 (b) 参照).

\section{4 安定把持のための可能な関節トルクベクトル}

前述したように，ロボットハンドが指と対象物の相対変位を させず安定的に対象物を把持するためには, 適当な一定の関節 トルクをあらかじめ与える必要がある。一組の接触点の位置と 把持姿勢を定めると，それに対応する安定把持のための可能な 関節トルクベクトルの空間が存在する。この節ではこのような 空間を求める方法について述べる.

式（11）より, 対象物に外力が作用してないとき, 安定把持 を維持するために，対象物に作用する一定の関節トルク $\boldsymbol{\tau}_{c}$ か らの合力 $\boldsymbol{W}^{T}\left(\boldsymbol{J}^{+}\right)^{T} \boldsymbol{\tau}_{c}$ がゼロになるか, あるいは内力の合力 からなる空間 $\left\{\boldsymbol{W}^{T}\left(\boldsymbol{I}_{3 M}-\boldsymbol{J J}^{+}\right) \boldsymbol{k}_{1}\right\}$ によって吸収されなけ ればならない，同様に，外力が作用しているときも，一定の関 節トルクからの合力を用いて不確定性をもつ外力を直接的に抵 抗することが不可能であるので, 安定把持のためにこの合力も 力空間 $\left\{\boldsymbol{W}^{T}\left(\boldsymbol{I}_{3 M}-\boldsymbol{J} \boldsymbol{J}^{+}\right) \boldsymbol{k}_{1}\right\}$ 内に存在すべきである.すな わち，関節トルクからの合力と内力の合力空間との間は

$$
\boldsymbol{W}^{T}\left(\boldsymbol{J}^{+}\right)^{T} \boldsymbol{\tau}_{c}+\boldsymbol{W}^{T}\left(\boldsymbol{I}_{3 M}-\boldsymbol{J} \boldsymbol{J}^{+}\right) \boldsymbol{k}_{1}=\mathbf{0}
$$

が成り立つ必要がある。言い換えると，安定把持を維持するた めに, 力空間 $\left\{\boldsymbol{W}^{T}\left(\boldsymbol{I}_{3 M}-\boldsymbol{J J}^{+}\right) \boldsymbol{k}_{1}\right\}$ が外力 $\boldsymbol{t}_{e}$ だけでなく, 関節トルクからの合力も吸収すべきである.そうでないと，方 向と大きさが不定な外力に対して対象物とハンドとの間で動き が生じる。したがって式（33）によって，各接触点の位置と把 持姿勢を与えたときに安定把持のための可能な関節トルクベク トル $\boldsymbol{\tau}_{c}$ の存在空間は次のように得られる.

$$
\begin{aligned}
\boldsymbol{S}_{J}=\left\{\boldsymbol{\tau}_{c} \mid \boldsymbol{\tau}_{c}=\right. & -\left[\boldsymbol{W}\left(\boldsymbol{J}^{+} \boldsymbol{W}\right)^{+}\right]^{T}\left(\boldsymbol{I}_{3 M}-\boldsymbol{J} \boldsymbol{J}^{+}\right) \boldsymbol{k}_{1} \\
& \left.+\left(\boldsymbol{I}_{L}-\boldsymbol{J}^{+} \boldsymbol{W}\left(\boldsymbol{J}^{+} \boldsymbol{W}\right)^{+}\right) \boldsymbol{k}_{s}\right\}
\end{aligned}
$$

ただし $\boldsymbol{k}_{s}$ は $L$ 次元任意ベクトルである. また, $\boldsymbol{k}_{1}=\boldsymbol{k}_{11}-\boldsymbol{k}_{12}$, $\boldsymbol{k}_{s}=\boldsymbol{k}_{s 1}-\boldsymbol{k}_{s 2}\left(\boldsymbol{k}_{11}, \boldsymbol{k}_{12}, \boldsymbol{k}_{s 1}, \boldsymbol{k}_{s 2} \geq \mathbf{0}\right)$ のように書き換える ことができるから，集合 $\boldsymbol{S}_{J}$ が凸多面錐であることが分かる.

もし $\left\{\boldsymbol{W}^{T}\left(\boldsymbol{J}^{+}\right)^{T} \boldsymbol{\tau}_{c}\right\} \perp\left\{\boldsymbol{W}^{T}\left(\boldsymbol{I}_{3 M}-\boldsymbol{J} \boldsymbol{J}^{+}\right) \boldsymbol{k}_{1}\right\}$ が成立す るとすれば, $\left[\boldsymbol{W}\left(\boldsymbol{J}^{+} \boldsymbol{W}\right)^{+}\right]^{T}\left(\boldsymbol{I}_{3 M}-\boldsymbol{J} \boldsymbol{J}^{+}\right) \boldsymbol{k}_{1}=\mathbf{o}$ より

$$
\boldsymbol{S}_{J}=\left\{\boldsymbol{\tau}_{c} \mid \boldsymbol{\tau}_{c}=\left(\boldsymbol{I}_{L}-\boldsymbol{J}^{+} \boldsymbol{W}\left(\boldsymbol{J}^{+} \boldsymbol{W}\right)^{+}\right) \boldsymbol{k}_{s}\right\} \text { (35) }
$$

となり, 可能な関節トルクからの合力はゼロとしかならない． これは, 力空間 $\left\{\boldsymbol{W}^{T}\left(\boldsymbol{I}_{3 M}-\boldsymbol{J J}^{+}\right) \boldsymbol{k}_{1}\right\}$ が全空間まで張って いないことを意味している．したがって，2.1節のパワーグラ スプの把持形態条件より，この場合の把持はパワーグラスプに なり得ないことが分かる. Fig. 4(d) はこの場合の一つの例を 示している.

また, $L<6$ (二次元平面内の運動では $L<3$ ) かつ $\operatorname{rank} \boldsymbol{J}^{+} \boldsymbol{W}=L$ の場合 (例えば Fig. 4 (a), (b), (c) の場合), $\boldsymbol{J}^{+} \boldsymbol{W} \in \boldsymbol{R}^{L \times 6}$ より集合 $\boldsymbol{S}_{J}$ が次のように求められる.

$$
\boldsymbol{S}_{J}=\left\{\boldsymbol{\tau}_{c} \mid \boldsymbol{\tau}_{c}=-\left[\boldsymbol{W}\left(\boldsymbol{J}^{+} \boldsymbol{W}\right)^{+}\right]^{T}\left(\boldsymbol{I}_{3 M}-\boldsymbol{J} \boldsymbol{J}^{+}\right) \boldsymbol{k}_{1}\right\}
$$

Fig. 5 Similarity of critical external force spaces 
さらに, $\left\{\boldsymbol{W}^{T}\left(\boldsymbol{J}^{+}\right)^{T} \boldsymbol{\tau}_{c}\right\} \perp\left\{\boldsymbol{W}^{T}\left(\boldsymbol{I}_{3 M}-\boldsymbol{J} \boldsymbol{J}^{+}\right) \boldsymbol{k}_{1}\right\}$ と $L<6$ かつ $\operatorname{rank} \boldsymbol{J}^{+} \boldsymbol{W}=L$ を共に満たす場合, 式（35）（36）によ り $\boldsymbol{S}_{J}=\mathbf{o}$ が得られる。この場合, 安定把持するための関節卜 ルクが存在しないので対象物の把持も不可能になる. Fig. 4 (e) はこの場合の一つの例を示している.

式 (34) は安定把持するための条件としてはまだ不十分であ る.リンクと対象物との実際の接触力は片側拘束であり静止摩 擦条件の範囲内にしか存在できない.したがって, 式 $(25)$ と 式 (4)（5）により，関節トルクベクトル $\boldsymbol{\tau}_{c}$ はさらに次のよう な凸多面錐空間内に存在すべきである.

$$
\boldsymbol{S}_{f}=\left\{\boldsymbol{\tau}_{c} \mid \boldsymbol{\tau}_{c}=\boldsymbol{J}^{T} \boldsymbol{V} \boldsymbol{k}_{v}, \quad \boldsymbol{k}_{v} \geq \mathbf{o}\right\}
$$

式（34）（37）より, 安定把持するための可能な関節トルクベ クトル $\boldsymbol{\tau}_{c}$ の空間 $\widehat{\boldsymbol{S}}$ が次式により得られる.

$$
\widehat{\boldsymbol{S}}=\boldsymbol{S}_{J} \cap \boldsymbol{S}_{f}=\left\{\boldsymbol{H} \boldsymbol{k}_{h} \mid \boldsymbol{k}_{h} \geq \mathbf{o}\right\}
$$

例えば, Fig. 4(a), Fig. 4(c) と Fig. 4(d)において $\mu_{1}=$ $\mu_{2}=0.3$ の場合, 可能な関節トルクベクトルの空間 $\widehat{\boldsymbol{S}}$ がそれ ぞれ次のように求められる。

$$
\begin{aligned}
& \boldsymbol{S}_{J a 1}=\left\{\left[\begin{array}{ll}
1 & -1
\end{array}\right] \boldsymbol{k}_{1 a 1} \mid \boldsymbol{k}_{1 a 1} \geq \mathbf{o}\right\}, \\
& \boldsymbol{S}_{f a 1}=\left\{[1] k_{v a 1} \mid k_{v a 1} \geq 0\right\}, \\
& \widehat{\boldsymbol{S}}_{a 1}=\left\{[1] k_{h a 1} \mid k_{h a 1} \geq 0\right\}, \\
& \boldsymbol{S}_{J c 1}=\left\{\left[\begin{array}{ll}
0.7 & -0.7 \\
0.7 & -0.7
\end{array}\right] \boldsymbol{k}_{1 c 1} \mid \boldsymbol{k}_{1 c 1} \geq \mathbf{0}\right\}, \\
& \boldsymbol{S}_{f c 1}=\left\{\left[\begin{array}{ll}
0.6 & 0.8 \\
0.8 & 0.6
\end{array}\right] \boldsymbol{k}_{v c 1} \mid \boldsymbol{k}_{v c 1} \geq \mathbf{0}\right\} \\
& \widehat{\boldsymbol{S}}_{c 1}=\left\{\left[\begin{array}{l}
0.7 \\
0.7
\end{array}\right] k_{h c 1} \mid k_{h c 1} \geq 0\right\} \text {, } \\
& \boldsymbol{S}_{J d 1}=\left\{\left[\begin{array}{rr}
-0.7 & 0.7 \\
0.7 & -0.7
\end{array}\right] \boldsymbol{k}_{s d 1} \mid \boldsymbol{k}_{s d 1} \geq \mathbf{0}\right\} \text {, } \\
& \boldsymbol{S}_{f d 1}=\left\{\left[\begin{array}{rr}
1 & 0 \\
0 & -1
\end{array}\right] \boldsymbol{k}_{v d 1} \mid \boldsymbol{k}_{v d 1} \geq \mathbf{0}\right\} \text {, } \\
& \widehat{\boldsymbol{S}}_{d 1}=\left\{\left[\begin{array}{r}
0.7 \\
-0.7
\end{array}\right] k_{h d 1} \mid k_{h d 1} \geq 0\right\}
\end{aligned}
$$

式 (38) は安定把持するための関節トルクベクトル方向の可 能な範囲を示している. 各関節から出せるトルクが制限される ので，これらの関節トルクベクトルの大きさも制限されている. ここで，安定把持するための関節トルクベクトルの大きさの最 大值の求め方を考える。まず，与えられた各関節の正負両側の 制限值 $\tau_{\mathrm{Pmax} i k}, \tau_{\mathrm{Mmax} i k}\left(i=1,2, \cdots, K, k=1,2, \cdots, L_{i}\right)$ に 対して, 決められた一つの関節トルクベクトル $\tau_{c}^{D}$ から求め られた各関節のトルク值で，それぞれに対応する $\tau_{\text {Pmaxik }}$ と $\tau_{\text {Mmaxik }}$ を割る。そして，得られたいくつかの商の中で正の一 番小さな值を $k_{\max }^{D}$ とすると, この関節トルクベクトル $\tau_{c}^{D}$ の 最大限 $\boldsymbol{\tau}_{c}^{\max }$ は

$$
\tau_{c}^{\max }=\tau_{c}^{D} k_{\max }^{D}
$$

によって求められる. $\tau_{c}^{\max }$ と同方向の $\tau_{c}$ で $\left\|\boldsymbol{\tau}_{c}\right\| \leq\left\|\tau_{c}^{\max }\right\|$ のように対象物を把持すれば，各指の関節では， $\tau_{\text {Mmaxik }} \leq$ $\tau_{i k} \leq \tau_{\mathrm{Pmax} i k}$ となるように関節トルク $\tau_{i k}$ が発生される.

\section{3. 最適なパワーグラスプの決定法}

\section{1 最適なパワーグラスプの定義}

ある物体をロボットハンドを用いたパワーグラスプによって 把持するとき，以下に挙げる要因の組み合わせによってパワー グラスプの形態は無数に存在する.

（1）ロボットハンドの形状（指の本数, 各指の関節数, 各 指リンクの長さ, ベースの形状)

（2）ロボットハンドと対象物の接触状態（接触点数, ロ ボットハンド側，対象物側それぞれからみた各接触点 の位置，各接触点における最大静止摩擦係数）

（3）ロボットハンドの各関節トルクの值

実際に把持をするときには無数のパワーグラスプの形態の中 から何らかの評価基準によって適当なものを選ぶ必要がある. そのためにまず，要求外力仕様というものを定義する．実現し ようとするパワーグラスプの限界外力空間が最低限含まなけれ ばならない外力の集合を要求外力仕様とする. 要求外力仕様は 六次元（平面内の運動では三次元）自由度をもつ多面凸空間と し，そのすべての頂点の集合によって表すものとする。一般に ロボットハンドの関節を駆動するモータのトルクには上限值が 存在するため, 大きいトルクを必要とするときにはモータも大 きいものを使わなければならない，同じ大きさの外力に抗する ときには関節トルクはなるべく小さい方が適当であると考え， ここでは最適なパワーグラスプを以下のように定義する.

最適なパワーグラスプ 要求外力仕様をその限界外力空間に含 むパワーグラスプのうち関節トルクが最大となる関節の関

節トルクが最小となるもの

上記の定義は次のように表現できる， $i$ 番目の指の $k$ 番目の 関節の関節トルクを $\tau_{i k}$ とし, 次の評価関数 $\Phi$ を定義する.

$$
\Phi \triangleq \stackrel{\max }{=}, k\left|\tau_{i k}\right|
$$

要求外力仕様をその限界外力空間に含むパワーグラスプを実 現する $\left[\begin{array}{ll}\boldsymbol{W} & \boldsymbol{J}\end{array}\right]$ と $\boldsymbol{\tau}$ の中で $\Phi$ を最小化するものが最適なパ ワーグラスプを奏現する $\left[\begin{array}{ll}\boldsymbol{W} & \boldsymbol{J}\end{array}\right], \boldsymbol{\tau}$ となる．

さらに，各関節の発生可能な最大トルクの大きさが異なりそ れを考慮に入れる場合, 次のような評価関数 $\Phi^{\prime}$ を最小化する ものを最適なパワーグラスプと定義する.

$$
\Phi^{\prime} \triangleq i, k \frac{\left|\tau_{i k}\right|}{\tau_{i k \max }}
$$

ここで, $\tau_{i k \max }(>0)$ は $i$ 番目の指の $k$ 番目の関節の発生可能 な最大トルクの大きさである.

\section{2 最適なパワーグラスプの決定法}

前節で定義した最適なパワーグラスプを求める方法を以下に 示す.ただしパワーグラスプの形態を決める要因の 1 番目である ロボットハンドの形と要因の 2 番目の中の接触点数はあらかじめ 決まっているものとする. また, 各関節の発生可能な最大トルク 
は同一であるとする. 式 (31) は $\boldsymbol{A} \triangleq\left[\begin{array}{ll}\boldsymbol{W} & \boldsymbol{J}\end{array}\right] \in \boldsymbol{R}^{3 M \times(6+L)}$ を用いて次式でまとめられる。

$$
\boldsymbol{A}^{T} \boldsymbol{f}=\left[\begin{array}{c}
-\boldsymbol{t}_{e} \\
\boldsymbol{\tau}
\end{array}\right]
$$

式（51）を $f$ について解くと次式を得る.

$$
\boldsymbol{f}=\left(\boldsymbol{A}^{+}\right)^{T}\left[\begin{array}{c}
-\boldsymbol{t}_{e} \\
\boldsymbol{\tau}
\end{array}\right]+\left(\boldsymbol{I}_{3 M}-\boldsymbol{A A ^ { + } ) \boldsymbol { k } _ { 2 }}\right.
$$

となる。ここで, $\boldsymbol{A}^{+} \in \boldsymbol{R}^{(6+L) \times 3 M}$ は $\boldsymbol{A}$ の疑似逆行列を表 L, $\boldsymbol{I}_{3 M}$ は $3 M$ 次元単位行列, $\boldsymbol{k}_{2}$ は $3 M$ 次元任意ベクトル である。式（52）と接触点に扔ける摩擦条件である式（16）を 用いて全探索的に最適なパワーグラスプを求める.

手順 1

要求外力仕様の頂点の集合を準備しこれを $\boldsymbol{T}$ とする。 また, 頂点の数が $n_{1}$ であるとする. ただし要求外力仕様は六次元自 由度を有するからその空間内に原点を含むように設定する。

\section{手順 2}

パワーグラスプの形態を決める要因の 2 番目の接触状態の各 接触点位置を決定することにより $\boldsymbol{A}$ が定まる。数值計算上の刻 みにより，考えられるすべての各接触点の位置が $n_{2}$ 組あると する.このうちの一つを式 (52) の $\boldsymbol{A}$ 抽よ゙゙ $\boldsymbol{A}^{+}$に代入する.

\section{手順 3}

関節トルク $\boldsymbol{\tau}$ (全関節数は $L$ ) の $i$ 番目の成分 $\tau_{i}$ が最大と なる場合を考える．相似な関節トルクベクトルに対してはその 臨界外力空間は相似なことから最大卜ルクを $\left|\tau_{i}\right|=1$ として 他の成分の絶対值は 0 から 1 までを $n_{3}$ 分割する刻みで全探索 するものとする。このとき $\boldsymbol{\tau}$ は $n_{3}^{L}$ 通りとなる.

手順 4

手順 3 で与えた $n_{3}^{L}$ 通りの $\boldsymbol{\tau}$ の一つが式（38）を満たすか どうかを確認し，満たせばこの $\boldsymbol{\tau}$ を式 $(52)$ に代入する。 そし て, 式 (52) の $\boldsymbol{t}_{\boldsymbol{e}} に \boldsymbol{T}$ のすべての成分を実数 $p$ 倍したもの をそれぞれ代入することで $n_{1}$ 個の式を得る. $p$ は 0 から刻み $\Delta p$ で大きくしていくものとする.

\section{手順 5}

手順 4 で用意した $n_{1}$ 個の式によって与えられる $\boldsymbol{f}$ は式 (52) の右辺第 2 項に自由度をもつためそれぞれの $\boldsymbol{k}_{2}$ を変化させる ことで $n_{1}$ 個の $\boldsymbol{f}$ すべてが摩擦条件である式 (16) を満足する 最大の $p=p_{\max 1}$ を求める.このとき手順 4 で選んだ $\boldsymbol{\tau}$ と相 似な関節トルクベクトルのうち最適なパワーグラスプとなるも のの最大の関節トルクの大きさは $1 / p_{\max 1}$ となる.

\section{手順 6}

手順 4 , 手順 5 を $n_{3}^{L}$ 通り計算をし, 求まった $p_{\max 1}$ のうち 最大のものを $p_{\max 2}$ とする.

\section{手順 7}

手順 3 から手順 6 を $L$ 通り計算をし，求まった $p_{\max 2}$ のう ち最大のものを $p_{\max 3}$ とする。ここで $1 / p_{\max 3}$ は $\boldsymbol{A}$ を固定 した場合の $\Phi$ の最小值である.

\section{手順 8}

手順 2 から手順 7 を $n_{2}$ 通り計算をし, 求まった $p_{\max 3}$ の うち最大のものを $p_{\max 4}$ とする。この $p_{\max 4}$ を与える $\boldsymbol{A}, \boldsymbol{\tau}$ によって表現される把持が最適なパワーグラスプとなり，そ のとき, 最大の関節トルクの大きさは $1 / p_{\max 4}$ となる。この $1 / p_{\max 4}$ は $\boldsymbol{A}, \boldsymbol{\tau}$ を探索したときの $\Phi$ の最小值である.

\section{4. 数 值 例}

Fig. 6 およびFig. 10 に示すような，ロボットハンドによっ て長方形の対象物を平面内把持する場合について，前章の方法 により最適なパワーグラスプを求める.

\section{1 対象物とロボットハンドの接触状態を固定した場合}

まず，本節の場合 (A) と (B) では Fig. 6, 場合 (C) では Fig. 10 のように接触状態をあらかじめ固定した場合について計算をす る.このとき行列 $\boldsymbol{A}$ は固定されるため, 前章の手順 7 の $p_{\max 3}$ を与える関節トルクを求める問題となる.

\section{(A) 摩擦係数が異なる場合}

平面把持のため限界外力空間は並進力二次元，モーメント一 次元の三次元空間となる.この空間内で要求外力仕様が Fig. 7 のような $( \pm 1, \pm 1, \pm 1)$ を頂点とする立方体で与えられるもの とする. 各接触点での最大静止摩擦係数がすべて等しく $\mu$ で あるとし， $\mu=0.1,0.3,0.5,1.0,1.5$ の場合について計算を行っ た。なおロボットハンド，対象物の姿勢と要求外力の対称性か ら， $\tau_{11}=-\tau_{21}, \tau_{12}=-\tau_{22}$ であるとした. Fig. 8 にそれぞれ の場合の $p_{\max 1}$ の值を示す.また，最適なパワーグラスプを 与える関節トルクは Table 1 のようになった。

Table 1 から接触点での最大静止摩擦係数が大きいほど, $\Phi\left(=i, k\left|\tau_{i k}\right|\right)$ は小さくて済み, かつ $\frac{\left|\tau_{12}\right|}{\left|\tau_{11}\right|}$ の值が大きくなる ことが分かる.また， $\mu=1.5$ の場合，実際の接触においてこ のように大きな摩擦係数が存在するかは別として, Fig.8(b)

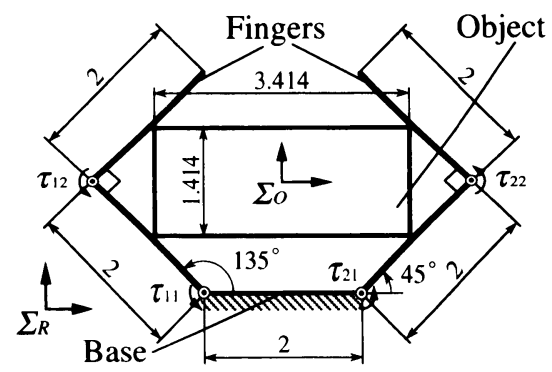

Fig. 6 Robot hand and object (I)

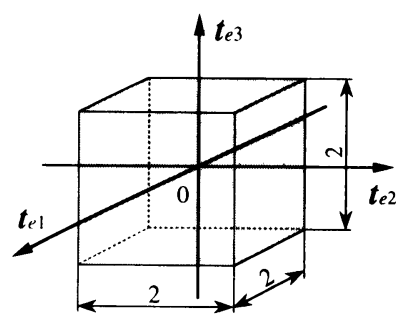

Fig. 7 Desired external force measure 


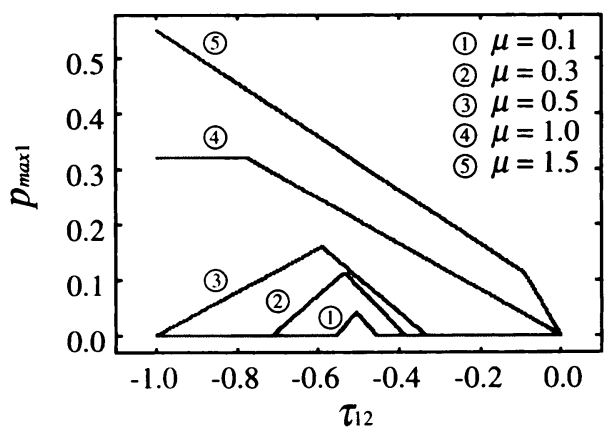

(a) Case when $\tau_{11}=-1$

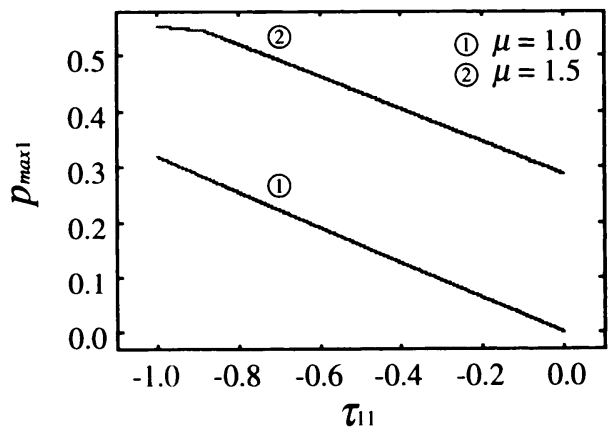

(b) Case when $\tau_{12}=-1$

Fig. $8 p_{\max 1}$ of 4.1 (A)

Table 1 Joint torques for optimal power grasp of 4.1 (A)

\begin{tabular}{|c||c|r|r|}
\hline$\mu$ & $p_{\max 3}$ & $\left|\tau_{11}\right|$ & $\left|\tau_{12}\right|$ \\
\hline \hline 0.1 & 0.037 & 27.03 & 14.32 \\
\hline 0.3 & 0.109 & 9.17 & 4.86 \\
\hline 0.5 & 0.154 & 6.49 & 3.77 \\
\hline 1.0 & 0.317 & 3.15 & 2.62 \\
\hline 1.5 & 0.549 & 1.80 & 1.82 \\
\hline
\end{tabular}

を見れば， $\left|\tau_{11}\right|=0$ のときもパワーグラスプとなることが分 かる。

(B) 要求外力仕様が異なる場合

ここでは重力が一定の方向に働くような場合に対応させて， あらかじめ要求外力仕様にオフセットを与える場合を考える. 要求外力仕様は Fig. 7 で表したものと，それを $\boldsymbol{t}_{e 2}$ 方向に \pm 1 ずらしたもの（これらは Fig. 6 の上下方向に重力が働く場合に 相当する）の 3 種類を比較する. $\mu=0.3$ とした. Fig. 9 にそ れぞれの場合の $p_{\max 1}$ の值を示す。また，最適なパワーグラ スプを与える関節トルクは Table 2 のようになった.

Table 2 から最適なパワーグラスプを与える| $\tau_{11} \mid$ の值は, 三つのケースで変わらないが, $\left|\tau_{12}\right|$ の值は, 要求外力仕様の オフセットが正から負になるにつれて小さくなることが分かる. このことから Fig. 6 の把持姿勢は図中で下向きの力に強いこと がいえる.またFig.9 を見ると，三つのケースで $p_{\max 1}$ の最 大値を与える $\tau_{12}$ の值はそれぞれ異なるが, $p_{\max 1}=0$ から $p_{\max 1} \neq 0$ に移行するときの $\tau_{12}$ の值は等しいことが分かる.

(C) 指の中間リングと指先を共に用いる場合

Fig. 10 に示すように指の中間リングと指先を共に用い

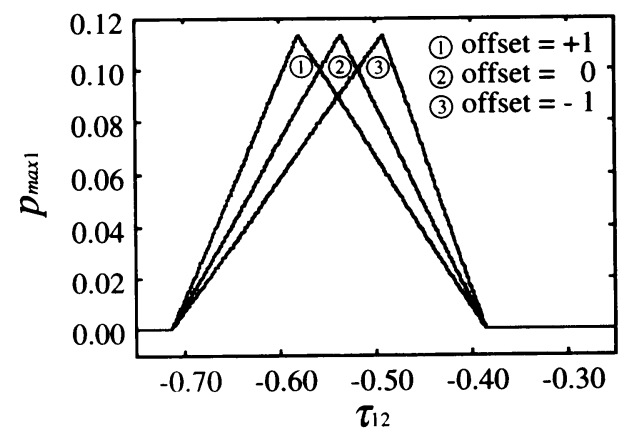

Case when $\tau_{11}=-1$

Fig. $9 p_{\max 1}$ of 4.1 (B)

Table 2 Joint torques for optimal power grasp of 4.1 (B)

\begin{tabular}{|c||c|c|c|}
\hline$t_{e 2}$ 's offset & $p_{\max 3}$ & $\left|\tau_{11}\right|$ & $\left|\tau_{12}\right|$ \\
\hline \hline+1 & 0.109 & 9.17 & 5.41 \\
\hline 0 & 0.109 & 9.17 & 4.86 \\
\hline-1 & 0.109 & 9.17 & 4.49 \\
\hline
\end{tabular}

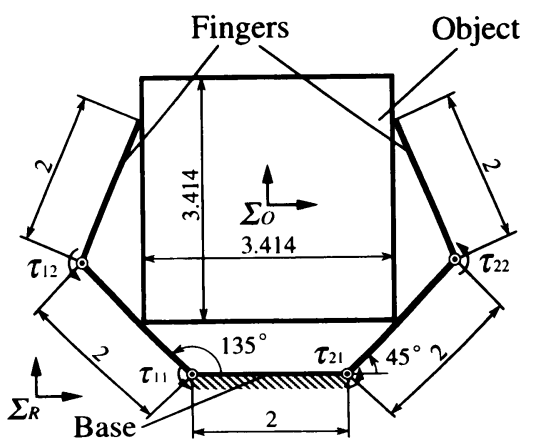

Fig. 10 Robot hand and object (II)

る場合について考える。ここで要求外力仕様も Fig. 7 の ような $( \pm 1, \pm 1, \pm 1)$ を頂点とする立方体とする．各接触 点での最大静止摩擦係数がすべて等しく $\mu=0.1,0.3,0.5,1.0,1.5$ の場合について計算を行った。な お口ボットハンド，対象物の姿勢と要求外力の対称性から, $\tau_{11}=-\tau_{21}, \tau_{12}=-\tau_{22}$ であるとした. Fig. 11 にそれぞれの 場合の $p_{\max 1}$ の值を示す. また，最適なパワーグラスプを与 える関節トルクは Table 3 のようになった.

Table 3 から場合 $(\mathrm{A})$ と比べると, 要求外力仕様が同様であ るパワーグラスプを実現するために，一部の中間リング接触の 代わりとした指先接触を用いる場合にはより大きな関節卜ルク および静止摩擦が必要となることが分かる。

4.2 対象物とロボットハンドの接触状態を変化させる場合

次に, Fig. 6 に示したような対象物とロボットハンドの接触 状態を変化させることで, 最適なパワーグラスプを探索する.

(A) ケース 1

Fig. 6 において対象物をロボットハンドに対して上下に動か して探索する. 対象物の下側の辺とロボットハンドのベース との距離を $y$ とし， $y$ を 0 から 0.05 刻みで上方に動かすも のとする. $\mu=0.1,0.3,0.5,1.0,1.5$ の場合について計算した. 


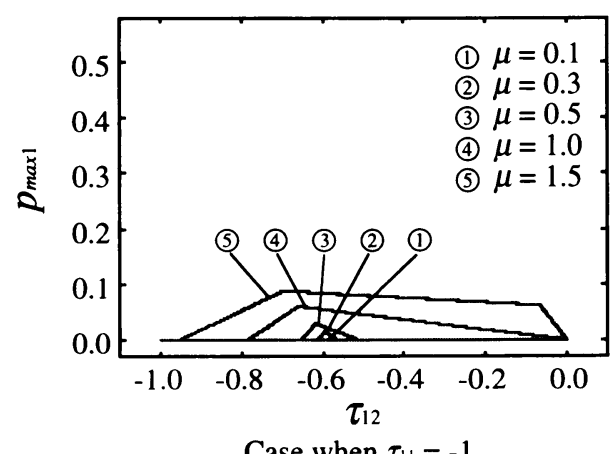

Case when $\tau_{11}=-1$

Fig. $11 p_{\max 1}$ of $4.1(\mathrm{C})$

Table 3 Joint torques for optimal power grasp of 4.1 (C)

\begin{tabular}{|c||c|c|c|}
\hline$\mu$ & $p_{\max 3}$ & $\left|\tau_{11}\right|$ & $\left|\tau_{12}\right|$ \\
\hline 0.1 & 0.000 & $\infty$ & $\infty$ \\
\hline 0.3 & 0.011 & 90.91 & 53.64 \\
\hline 0.5 & 0.026 & 38.46 & 23.46 \\
\hline 1.0 & 0.058 & 17.24 & 11.03 \\
\hline 1.5 & 0.087 & 11.49 & 7.93 \\
\hline
\end{tabular}

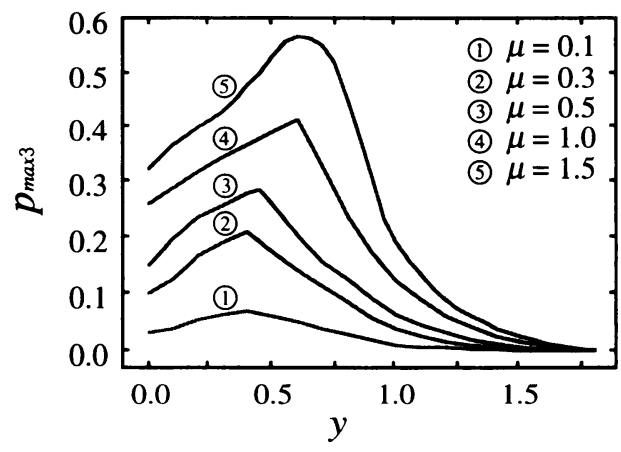

Fig. $12 p_{\max 3}$ of $4.2(\mathrm{~A})$

Table 4 Joint torques for optimal power grasp of 4.2 (A)

\begin{tabular}{|c||c|c|r|r|}
\hline$\mu$ & $y$ & $p_{\max 4}$ & $\left|\tau_{11}\right|$ & $\left|\tau_{12}\right|$ \\
\hline \hline 0.1 & 0.40 & 0.069 & 14.49 & 14.49 \\
\hline 0.3 & 0.40 & 0.208 & 4.81 & 4.81 \\
\hline 0.5 & 0.45 & 0.283 & 3.53 & 3.53 \\
\hline 1.0 & 0.60 & 0.411 & 2.31 & 2.43 \\
\hline 1.5 & 0.60 & 0.568 & 1.72 & 1.76 \\
\hline
\end{tabular}

Fig. 12 にそれぞれの場合の $p_{\max 3}$ の值を示す。また，最適な パワーグラスプを与える関節トルクおよび $y$ の值は Table 4 の ようになった。このときの把持姿勢は Fig.13のようになった。

Table 4, Fig. 13 より，最適なパワーグラスプを与える把持 姿勢は前節で固定した対象物の位置 $(y=0.71)$ より下で把持 する場合であることが分かる. また, 最大静止摩擦係数が大き いほど $\Phi\left(=i, k\left|\tau_{i k}\right|\right)$ は小さくて済むことが分かる.

(B) ケース 2

要求外力仕様が Fig. 7 の前後方向に非対称場合において, 対 象物を上下 $(y$ 方向 $)$ のみでなく左右 $(x$ 方向)にも動かして 探索することを考える. ただし Fig. 6 の対象物の位置を $x=0$

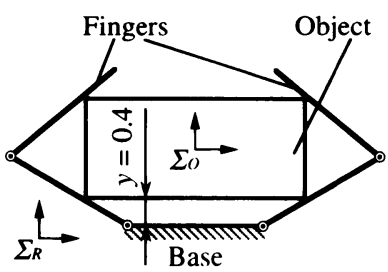

(a) Case when $\mu=0.1,0.3$

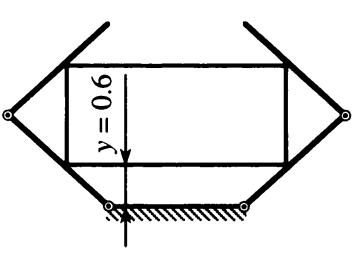

(b) Case when $\mu=1.0,1.5$
Fig. 13 Optimal power grasps of 4.2 (A)

Table $5 p_{\max 3}$ of $4.2(\mathrm{~B})$ with $\boldsymbol{t}_{e 1}$ 's offset

\begin{tabular}{|c|c||c|c|c|c|c|}
\hline \multicolumn{2}{|c||}{} & \multicolumn{5}{c|}{$x$} \\
\cline { 2 - 7 } \multicolumn{2}{|c|}{} & -0.14 & -0.07 & 0 & 0.07 & 0.14 \\
\hline \hline \multirow{4}{*}{$y$} & 0 & 0.071 & 0.074 & 0.071 & 0.067 & 0.063 \\
\cline { 2 - 7 } & 0.20 & 0.112 & 0.116 & 0.120 & 0.118 & 0.116 \\
\cline { 2 - 7 } & 0.40 & 0.131 & 0.156 & 0.172 & $* 0.180$ & 0.162 \\
\cline { 2 - 7 } & 0.60 & 0.102 & 0.111 & 0.113 & 0.124 & 0.125 \\
\cline { 2 - 7 } & 0.80 & 0.063 & 0.068 & 0.073 & 0.068 & 0.060 \\
\cline { 2 - 7 } & 1.00 & 0.031 & 0.033 & 0.036 & 0.032 & 0.030 \\
\cline { 2 - 7 } & 1.20 & 0.013 & 0.014 & 0.015 & 0.014 & 0.013 \\
\hline
\end{tabular}

Table $6 p_{\max 3}$ of 4.2 (B) without offset

\begin{tabular}{|c|c||c|c|r|c|c|}
\hline \multicolumn{2}{|c||}{} & \multicolumn{5}{|c|}{$x$} \\
\cline { 2 - 7 } \multicolumn{2}{|c||}{-0.14} & -0.07 & \multicolumn{1}{c|}{0} & 0.07 & 0.14 \\
\hline \hline \multirow{4}{*}{$y$} & 0 & 0.068 & 0.071 & 0.100 & 0.071 & 0.068 \\
\cline { 2 - 7 } & 0.20 & 0.120 & 0.132 & 0.166 & 0.132 & 0.120 \\
\cline { 2 - 7 } & 0.40 & 0.143 & 0.171 & ${ }^{*} 0.208$ & 0.171 & 0.143 \\
\cline { 2 - 7 } & 0.60 & 0.109 & 0.112 & 0.140 & 0.112 & 0.109 \\
\cline { 2 - 7 } & 0.80 & 0.061 & 0.072 & 0.083 & 0.072 & 0.061 \\
\cline { 2 - 7 } & 1.00 & 0.028 & 0.035 & 0.039 & 0.035 & 0.028 \\
\cline { 2 - 7 } & 1.20 & 0.013 & 0.015 & 0.016 & 0.015 & 0.013 \\
\hline
\end{tabular}

Table 7 Joint torques for optimal power grasp of 4.2 (B)

\begin{tabular}{|c||c|c|c|c|c|c|c|}
\hline$t_{e 1}$ 's offset & $x$ & $y$ & $p_{\max 4}$ & $\tau_{11}$ & $\tau_{12}$ & $\tau_{21}$ & $\tau_{22}$ \\
\hline \hline-1 & 0.07 & 0.40 & 0.180 & -5.56 & -5.22 & 5.11 & 5.56 \\
\hline 0 & 0.00 & 0.40 & 0.208 & -4.81 & -4.81 & 4.81 & 4.81 \\
\hline
\end{tabular}

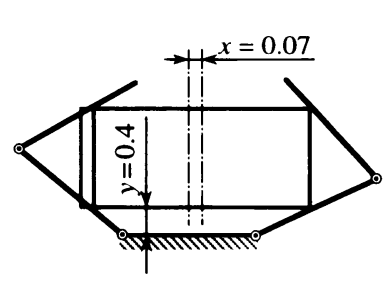

(a) Case with $t_{e} \mid$ 's offset

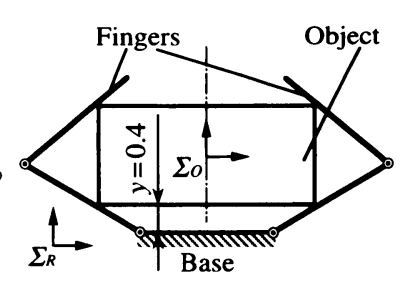

(b) Case without offset
Fig. 14 Optimal power grasps of 4.2 (B)

とし右向きを正に変位 $x$ で探索する。ここでは要求外力仕様が Fig. 7 のものと, それを $\boldsymbol{t}_{e 1}$ 方向に -1 オフセットしたものと

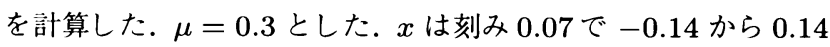
まで, $y$ は刻み 0.05 で 0 から 1.20 までを探索した. Table 5 にオフセットありの場合, Table 6 にオフセットなしの場合の $p_{\max 3}$ の值を示す．その中で*を付けたものが $p_{\max 3}$ の最大 值，すなわち $p_{\max 4}$ である. また，最適なパワーグラスプを 与える関節トルクおよび $x, y$ の值は Table 7 のようになった。 
そのときの姿勢を Fig. 14 に示す. 最適なパワーグラスプは， オフセットなしの場合には $x=0$ のとき与えられるのに対し て，オフセットありの場合には $x=0.07$ という対象物がやや 右よりの位置にくる把持姿勢で与えられた。

\section{5. 結言}

本論文では，指リンクと物体との接触による力空間の自由度 に関する解析に基づいて, ロボットハンドの中間リンクも物体 に接触させることで実現するパワーグラスプの条件および力学 特性について考察した。ついで安定把持するための可能な関節 トルクの存在範囲を与えた。さらに, 同じ物体を把持する場合 でも様々な要因からいくつもの形態が存在するパワーグラスプ の中で最適なパワーグラスプを定義し, その決定方法を提案し た．その方法に基づいて数值例によって最適なパワーグラスプ を計算した。パワーグラスプの条件の中に摩擦条件が含まれる ことからも明らかなようにパワーグラスプでは接触点での最大 摩擦係数に対する依存度が大きいことが顕著であった。

本手法では，対象物を三次元空間内運動において上下左右前 後に（または二次元平面内運動において上下左右に）動かして 全探索するような場合には, 刻みを小さくすると計算量が大変 多くなり実用的とはいえない. そのため実際にパワーグラスプ の計画を行うときには，まず大きな刻みによる計算もしくは人 間の直感的な判断によってある程度探索範囲を限定してから本 手法を適用するなどの工夫が必要であると考えられる。

\section{参 考 文 献}

[1] A. Bicchi: "On the Probrem of Decomposing Grasp and Manip- ulation Forces in Multiple Whole-limb Manipulation," Robotics and Autonomous Systems, vol.13, pp.127-147, 1994.

[2] K. Mirza and D.E. Orin: "General Formulation for Force Distribution in Power Grasp," Proc. of IEEE Int. Conf. on Robotics and Automation, vol.1, Apr. 1994, pp.880-887.

[3] M.R. Cutkosky: "On Grasp Choice, Grasp Models, and the Design of Hands for Manufacturing Tasks," IEEE Trans. on Robotics and Automation, vol.5, no.3, pp.269-279, 1989.

[4] Y. Zhang and W.A. Gruver: "Definition and Force Distribution of Power Grasps," Proc. of IEEE Int. Conf. on Robotics and Automation, vol.2, Apr. 1995, pp.1373-1378.

[5] 小俣, 永田：“多指ハンドによるパワーグラスプの力学的特性”, 日 本ロボット学会誌, vol.13, no.4, pp.525-531, 1995.

[6] 中村, 張, 吉本: “パワーグラスプとそのロバスト性の評価法”, 日 本ロボット学会誌, vol.13, no.6, pp.866-874, 1995.

[7] 張, 中村, 吉本: “不完全な接触をもつ把持の力学的多面凸解析”, 日 本ロボット学会誌, vol.14, no.1, pp.105-113, 1997.

[8] 張, 中村, 吉本：“パワーグラスプを含む一般的な把持とあやつりの 力学”, 日本ロボット学会誌, vol.15, no.2, pp.207-215, 1997.

[9] 布川, 中山, 谷野: 線形代数と凸解析. pp.125-187, コロナ社, 1991.

[10] 吉川：“把持と操りの基礎理論 1. 受動拘束と能動拘束”, 日本ロボッ 卜学会誌, vol.13, no.7, pp.950-957, 1995.

[11] 余, 横小路, 中須, 吉川: “複数のロボット指による環境と接触している 物体の準動的操作”, 日本ロボット学会誌, vol.13, no.6, pp.875-885, 1995.

[12] Y.Yu and T. Yoshikawa: "Evaluation of Contact Stability between Objects," Proc. of IEEE Int. Conf. on Robotics and Automation, vol.1, Apr. 1997, pp.695-702.

[13] Y. Yu, K. Takeuchi and T. Yoshikawa: "Optimization of Robot Hand Power Grasps," Proc. of IEEE Int. Conf. on Robotics and Automation, vol.4, May 1998, pp.3341-3347.

[14] J. Kerr and B. Roth: "Analysis of Multifingered Hands," Int. Jour. of Robotics Research, vol.4, no.4, pp.3-17, 1986.

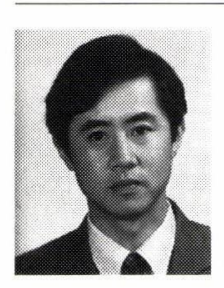

\section{余永 (Yong $\mathrm{Yu}$ )}

1957 年 1 月 29 日生. 1991 年京都大学大学院工学 研究科博士前期課程修了, 1995 年同大学大学院工 学研究科博士後期課程修了. 鹿児島大学工学部機 械工学科講師を経て, 1999 年同助教授となり現在 に至る。ロボットによる組立作業の自動計画，複数 ロボット機構の協調, アクティブセンシングなどに 興味を持つ. 博士 (工学). システム制御情報学会, 米国 IEEE 学会 などの会員.

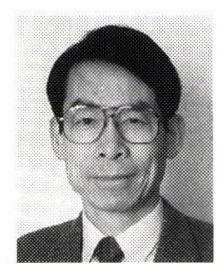

吉川恒夫 (Tsuneo Yoshikawa)

1941 年 12 月 19 日生. 1964 年京都大学工学部精 密工学科卒業, 1969 年同大学大学院工学研究科博 士課程修了, 同大学工学部助手, 1970 年同助教授, 1986 年同教授 (オートメーション研究施設, 1989 ～1991 年応用システム科学教室，1991 年より機械 工学教室)。1994 年組織変更により, 同大学大学院 工学研究科教授（機械工学専攻）となり現在に至る。その間 1973〜 1975 年米国 NASA マーシャル宇宙飛行センターNRC 準研究員. 口 ボット工学, メカトロニクス, 制御工学の研究に従事. 工学博士. シ ステム制御情報学会, 日本機械学会, 計測自動制御学会, 日本バー チャルリアリテイ学会, 米国 IEEE 学会などの会員.

(日本ロボット学会正会員)

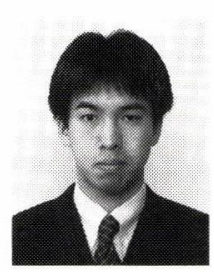

竹内賢一 (Kenichi Takeuchi)

1972 年 4 月 21 日生. 1995 年京都大学工学部機械 工学科卒業, 1997 年同大学大学院工学研究科機械 工学専攻博士前期課程修了. 同年 (株) トヨタ自動 車入社。在学中, ロボットハンドによる把持と操り に興味を持つ。 